\title{
Blowing the Whistle in the EU: A Policy Analysis of the Agenda-Setting of the Proposal for a Whistleblowers Protection Directive
}

\author{
Cecilia Ivardi Ganapini, Johanna Rick1
}

\begin{abstract}
Scandals concerning wrongdoings of multinational corporations and governments are inescapable in the news. "Blowing the whistle" on these is often constrained out of fear of retaliation, which is why in April 2018, a Directive to assure protection to whistleblowers was proposed. Tracing the origins of the process is complicated because there are several actors operating in a multilevel polity. Hence, Kingdon's multiple-streams model is applied to legislative texts and several news outlets, and inferences are drawn to describe the facets of the rise of whistleblowers protection on the EU agenda. This paper finds that the Greens Parliamentary group became a policy initiator after being urged by Transparency International to act. The Greens justified the need to act with old arguments, which however acquired momentum only when the political climate soothed after the scandals of LuxLeaks and Panama Papers.
\end{abstract}

\section{Introduction}

Public opinion was completely divided over Julian Assange's innocence or guilt when, on 11 April 2019, he was forcibly removed from the Ecuadorian embassy in London and jailed at Belmarsh High-Security prison over a bail breach. Assange is the founder of Wikileaks, an online platform containing confidential or restricted files from governments, private companies or other entities ("What is Wikileaks", 2015). Some considered Assange a hero for having revealed, among others, "the horrors of war carried out in our name by the US, NATO forces [in Iraq and Afghanistan (n.d.a.)]" (Da Silva Marques, 2019, para. 6) and condemned his imprisonment in "Britain's Guantanamo Bay" as an assault on freedom of the press (Winterman, 2004). Others, however, pointed to his activity as an "uncritical and enthusiastic laundromat for Russian intelligence [...] publishing material with little or no newsworthiness but calculated to undermine American interests" ("Julian Assange: journalistic hero", 2019, para. 9). What followed, on 23 May 2019, was the filing of 17 charges by the United States (US) Justice Department which accused Assange of violating the Espionage Act by leaking classified military and diplomatic documents ("Julian Assange in the Ecuadorian embassy", 2019).

${ }_{1}$ Cecilia Ivardi Ganapini received a bachelor degree in European Studies at Maastricht University in 2019. At the moment she takes a Master in Political Economy of Europe at the London School of Economics and Political Science. Contact: cecilia.ivardiganapini@gmail.com;

Johanna Rick received a bachelor degree in European Studies at Maastricht University in 2019. At the moment she takes a Master in International Relations and Diplomacy at Leiden University. Contact: rickjohanna@gmail.com. 
Usually, someone who "reports (within the organisation concerned or to an outside authority) or discloses (to the public) information on a wrongdoing obtained in a work-related context", is considered a whistleblower (European Commission [EC], 2018a, p. 1). Whistleblowing has two defining properties, namely the release of information is deliberate and it happens through unconventional ways because normal disclosure channels are not available (Jubb, 1999). It goes beyond the scope of this research to establish whether Assange is a whistleblower or not, and to decide on his innocence or guilt. However, to understand and develop informed opinions on current issues such as Assange's arrest, it is useful to understand the underlying legal framework and its interpretation.

Blowing the whistle is problematic, most importantly because one fears retaliation. This is why the European Union (EU) perceives the lack of adequate whistleblower protection as having potentially negative effects on public interests. It also infringes upon human rights such as freedom of expression and of the media, which is the context for the proposal of a Whistleblower Protection Directive (hereby: the Directive) on 23 April 2018 (EC, 2018c). Several recent scandals such as Dieselgate, Luxleaks, the Panama Papers and Cambridge Analytica could have hinted to a need for whistleblower protection to ensure the safe uncovering of unlawful activities (EC, 2018c, para. 1). Ensuring such safeguard is not easy, as whistleblowing is framed differently across the Member States of the EU (e.g. Schulze, 2015), and the legal framework is so fragmented that only four EU countries had "acceptable" levels of whistleblowers protection in 2013 (Transparency International [TI], 2013). In this multifaceted atmosphere, relating the Directive to specific events and establishing causation is extremely problematic. To understand how agenda-setting and real-world events interplayed in this instance, Kingdon's model (1983) is a useful tool. In short, the model concerns actors recognising problems, generating policy proposals to induce changes, and engaging in political activities such as lobbying. The model is used to answer the question: How did whistleblowing protection rise on the agenda of the EU?

This topic contributes to the academic debate first but not only because research on it is lacking. For one, the EC proposed the Directive just a year before this paper was started, which means the initiative is extremely recent and this work is relatively innovative. In addition, whistleblowing has increased as a phenomenon with technological developments such as the open internet and the existence of specific channels for reporting. Second, although thanks to social media people are more aware than ever of what surrounds them, research on whistleblowing protection is less focused on the EU than it is on the US. Third, pre-decision processes remain relatively unexplored territory, probably also because of the need for a case-by-case approach (Kingdon, 1983, p. 1).

"Agenda" indicates a list of subjects to which officials give serious attention at a given time. The "given time" in this case is from 2013, when a call for action was first voiced by the European Parliament (EP), until 2018, when the EC proposed the Directive. Although this study does not have predictive aims, interpreting the reasons behind the composition of the agenda is crucial for understanding policy-making processes, as the agenda determines what will be subject to decision-making and the terms by which it is discussed (Princen, 2010). The underlying logic can serve as an analytical tool and be applied to other initiatives for greater transparency, hence this research can serve as a support for the average citizen's understanding of the functioning of the EU, the democratic accountability of which is not to be taken for granted (Follesdal and Hix, 2006).

In order to achieve this, this paper first reviews the concept of whistleblowing and the literature on the issue of whistleblowers protection in different legal systems. Second, it details the theoretical framework utilised to understand the phenomenon, the Kingdon model. Third, the paper is divided into three 
sections, one for each part that the theoretical model suggests, namely the problem, political and policy streams and then brings them together in the discussion of the policy window. Fourth, a conclusion is drawn on the process of agenda-setting in the case of the Directive and avenues for further research are suggested.

\section{Different Views on Whistleblowers Protection Frameworks}

This section reviews the literature concerned with whistleblowers, first from an ethical perspective and then from a legal standpoint. The academic literature concerned with whistleblowing often incurs into problems when trying to define it, as some see whistleblowers as "traitorous violators of organizational loyalty norms" and others perceive them as "heroic defenders of values considered to be more important than company loyalty" (Rothschild and Miethe, 1999). Definitions also vary according to the discipline. In business ethics, whistleblowing is seen as dissent in response to an ethical dilemma, namely the one between loyalty to the targeted organization and loyalty to one's self and system of values. This ethical tension is predominant in the discussion and leads some scholars to differentiate professional morality from ethics. Although some consider ethics and morality as synonyms, Bouville (2008) understands ethics as a general way of discerning wrong from right, which however is not exclusive in the sense that two things can be right at the same time. By contrast, morality is a side of ethics which is supposed to guide men's lives and therefore provides for mutually exclusive alternatives (Williams, 1985). Hence, because whistleblowing pertains to the sphere of morality, it needs no justification, rendering whistleblowers "saints of secular culture" (Grant, 2002). Nevertheless, other scholars conceptualise whistleblowing as an activity which goes against the ethical duty of loyalty to the organization (Larmer, 1992). The need for an ethical rationale is not only a requisite for blowing the whistle but is also needed to cope with the consequences of blowing the whistle. In this regard, several studies (Glazer and Glazer, 1989; Gunsalus, 1998; Jos, Tompkins and Hays, 1989; Rothschild and Miethe, 1999) showed that even when whistleblowing is acknowledged to be for the public good, it hinders possibilities to have a later career, a stable financial situation and a family life and leads to victimization. In this regard, the public good is considered to be served when "malfeasance is made known to affected parties and government agencies are able to take appropriate corrective action" (Callahan, Dworkin and Lewis, 2004, p. 905). In sum, this paper understands whistleblowing as a moral activity in the sense that it defends the public interest over the interest of private parties and considers that this is the moral grounds conceived by the EU, in order to protect this activity.

Whistleblowing is also seen as a control mechanism that specific administrative structures have to protect or reward. Because the scope of the Directive concerns protection exclusively, what follows is an account of the studies dealing with the legal protection of whistleblowing. Legal scholarship diverges around the ethical faultline between those who regard the public interests as sufficient reasons to justify the exposition of often confidential information and those who fear umbrella impunities for corporate espionage. The legal framework differentiates between private sector whistleblowing, where an employee reports any corporate misbehaviour internally or externally, and which is less high-profile than the public sector one. This is because corporate structures facilitate the hiding of wrongdoings and corporations can dismiss the reporter more easily than in the public sector, where the pressure for taking action is higher. Partly due to the lack of media attention, private sector whistleblowing is less protected than the public sector one. Nonetheless, it is more frequent, as one-third of a sample companies interviewed by the Organisation for Economic Co-operation and Development (OECD) in 2015 had no written policy to protect 
whistleblowing, while $84 \%$ of the public ones did (OECD, 2016, p. 12; EC, 2018b). In addition, since public whistleblowing concerns misconduct of the government, such cases usually generate higher media attention, as can be seen in the case of Edward Snowden in 2013, who revealed classified information of the global mass surveillance programme of the US National Security Agency (NSA) (Salvo, 2016).

Whistleblower protection in the EU diverged severely between the Member States before the adoption of the Directive "with some countries, such as Ireland, having good laws and other countries, such as Cyprus, having practically none" (TI, 2018). One of the countries with "adequate" protection for whistleblowers is the UK, with its Public Interest Disclosure Act (PIDA). This law's novelty stems from the fact that it covers both private and public sector whistleblowing (Worth, 2013). It is exemplary in that other states have used it as a model for their own legislation and scholars even abstracted a three-tiered model from it to assess the different legislations on the theme (Vandekerckhove, 2010). In the first tier of the model, the information does not leave the organization since reporting is internal to the superior or to the relevant department. Should this be ineffective, the whistleblower informs an agent acting on behalf of civil society in the second tier. This takes the information regarding malpractice out of the company and thus already functions as a deterrent, as the reporter fears retaliation. If this agent fails to rectify the situation and does not take appropriate action, the third tier is invoked, which involves informing the public. This three-tiered model aims to establish that companies and organisations are not immediately publicly accountable for any misbehaviour, but this occurs only if they fail to respond to internally raised concerns (Vandekerckhove, 2010).

Using such models, several scholars have addressed the protection granted in specific countries such as Japan (Coney and Coney, 2016) or the US, specifically through the Sarbanes-Oxley Act of 2002, and even argue that the latter represents the highest form of protection granted to whistleblowers across the globe (Nyreröd and Spagnolo, 2018). This is because the US goes beyond granting protection and even secures financial incentives as rewards for whistleblowing in key regulatory areas such as federal procurement and tax enforcement. This element is not present neither in the Directive nor in the legislation of the best-performing countries in the EU (Worth, 2013; Wolfe et al, 2014), which, as was already mentioned, exclusively focus on protection. Concerning Europe, despite the lack of scholarly research on the Directive at hand, there is a consistent body of literature that details the whistleblower protection legislation in place in the different Member States, and the internal differences which are likely to create disparities in implementation (e.g. Vandekerckhove, 2010). Several reasons can account for Member States reluctance to regulate the matter at the European level. For instance, since especially public whistleblowing could reveal sensitive government information of the Member States, it can be assumed that the national governments hesitate to harmonise their legislation in this area (Worth, 2013). Because of this, Vandekerckhove (2010) argued that Europe could remain a place of diverse policy-making, yet with a common foundation. By contrast, researchers from organizations such as TI, call for a common framework to protect whistleblowers within companies, which could be used to offer protection also to journalists, whose investigative activities have proved deadly is some recent instances (Nyreröd and Spagnolo, 2018). This fragmented context offers some primary elements useful to understand the circumstances surrounding the Directive. Nevertheless, because these laws and concepts are not necessarily recent, understanding why the Directive was proposed at the time it was is puzzling. In other words, although the need for it seems pressing, from the scholarly perspective it is not intuitive that the issue arose on the agenda in 2013. This is the gap in the literature that this paper aims to fill, through a policy study that uses a comprehensive theoretical framework, which is detailed in the next chapter. 


\section{Theoretical Framework}

This chapter describes the analytical tools used to develop the policy analysis.

\subsection{Kingdon's Model: A Revolution in Policy Analysis}

Kingdon's streams model is the theoretical and methodological foundation of this paper. The core assumption of the model is that "public policy is not one single actor's brainchild", even within one case study and because of this, attempting to pinpoint a single origin for policy formation is vain (Barzelay and Gallego, 2006, p.71). This is because ideas can come from anywhere and usually do not have only one origin, thus trying to trace them back only gives rise to an infinite regression. Another reason why it is futile to try to trace the birth of ideas is that nobody leads anybody else in the development of policies, as it is a combination of factors that is responsible for the movement of an issue onto the agenda. From a theoretical perspective, this model is extremely innovative as it tries to go beyond the usual political science preoccupation with pressure and influence. By contrast, Kingdon captures "the fluidity of policymaking and the role played by chance and human creativity" (Natali, 2004, p. 1078), and the key idea that ambiguity is an indispensable part of the policy process (e.g. Zahariadis, 2008), which make the model suitable to investigate the research question. Although Kingdon (1983) developed the framework in relation to the healthcare system in the US, he borrowed some key concepts from EU scholars such as Haas (1968) and consequently there exists an "almost uncanny resemblance between this description of US policymaking and the perceptions of key actors in the EU policy process" (Richardson, 2006, p. 190) and can be employed to study the EU.

The model potentially criticises the policy networks approach. The latter envisages sets of formal and informal linkages between governmental and informal actors, which render the actors ultimately interdependent and posits that policy emerges from the interactions between them (Rhodes, 2008). By contrast, Kingdon's multiple-streams model allows for more freedom and does not explicitly attribute developments to specific actors. The model also opposes the traditional idea of the policy cycle. This reflects the birth and development of policies through the following phases: agenda setting, analysis of the policy issue, formulation of policy solutions, decision-making to adopt a certain solution, implementation of the chosen policy and evaluation of the policy (Howard, 2005). Although the phase of the policy cycle to which this research would generally pertain is agenda-setting, the strength of the model lies in the idea that the reality of policy-making cannot be perfectly encapsulated in predefined chronological phases. Therefore, the focus of the paper is still the way in which particular subjects become the focus of the attention of policy-makers (Kingdon, 1983, p. 3) but when it refers to agendasetting, it does not restrict itself to traditional agenda-setting, but encompasses also parts of other phases such as policy formulation. Furthermore, because of the multi-layered policy processes and the numerous interactions between EU institutions, there is not one single agenda but as many different agendas as there are EU institutions, which may even overlap (Princen, 2010, p. 109). In this research, the focus is on how protection for reporting persons was incorporated into a proposal for a Directive, and because the EC has the exclusive right to make legislative proposals, the EC's agenda is deemed to be the most relevant unit of analysis, although it is necessary to refer to other actors' agendas for a complete account of the phenomenon. 


\subsection{The substance of the model}

The substance of the model consists of the processes by which issues come into prominence. Kingdon (1983) discusses a crisis (problem recognition), a process of gradual accumulation of knowledge and perspectives among specialists (generation of policy proposals) and events such as shifts in public opinion, elections, lobbying campaigns and changes in administration (political occurrences). Problem recognition produces the problem stream, which consists of problem perceptions among policymakers, while the policy stream originates from the generation of policy proposals, which consists of proposals for government action. Then, the political events are captured in the political stream. Although it may be counterintuitive, the three streams develop independently from each other, which concretely means that solutions develop independently from problems. Nevertheless, even Kingdon admits that the process is never completely random and some sort of pattern emerges within each stream and within the couplings of problems with solutions (Richardson, 2006, p. 19).

Despite this, the streams have only a descriptive function, as the real explanatory tool is the temporal conjunction of the three separate sub-processes (Barzelay and Gallego, 2006). This can bring the streams together in a policy window, which corresponds to the moment when an issue moves to the top of the political agenda. The policy window usually opens in the problem or in the politics streams and constitutes a trigger that determines the way issues are debated. For instance, the Madrid and London bombings in 2004 and 2005 were policy windows for a new way to conceive and debate terrorism (Ackrill, Kay and Zahariadis, 2013). This explains why a certain policy may appear as a solution to very different problems. For instance, the EU Tobacco Products Directive, with a rather visible impact of EU legislation in a citizen's every life, requires a 75\% health warning labelling on the product. The policy solution of a $75 \%$ marking has been re-used various times, such as in the Single Use Plastic Directive, which requires the same label detailing the wrong disposal of plastic products. In this case, the policy idea had developed independently from the plastics pollution problem, but was coupled with it when the situation became favourable.

Kingdon's argument is that each of the streams can serve as an impetus or a constraint for an issue to rise on the agenda. To achieve this, the key actors can exploit the conjunction as an impetus, thereby boosting a subject higher on the agenda, or as a constraint, meaning that consideration for the subject diminishes. Concretely, when a suitable problem arises and a policy window opens, a policy entrepreneur is the person or the organisation who couples the three streams together and crafts meaning within the seemingly-chaotic context, because he/she is willing to invest their resources in return for future policies they favour. Policy entrepreneurs can be both inside and outside the EU, and while those inside are central but have less control over the alternatives that are considered and their implementation, those outside include interest groups, researchers, academics, consultants and media. Although the line between inside and outside actors might be difficult to draw, a distinction that is extremely meaningful is that between visible and hidden groups. Since the visible ones receive significant more press and public attention than the hidden ones, they have a different effect because evident actors have a say on the agenda while hidden ones decide on the alternatives. 


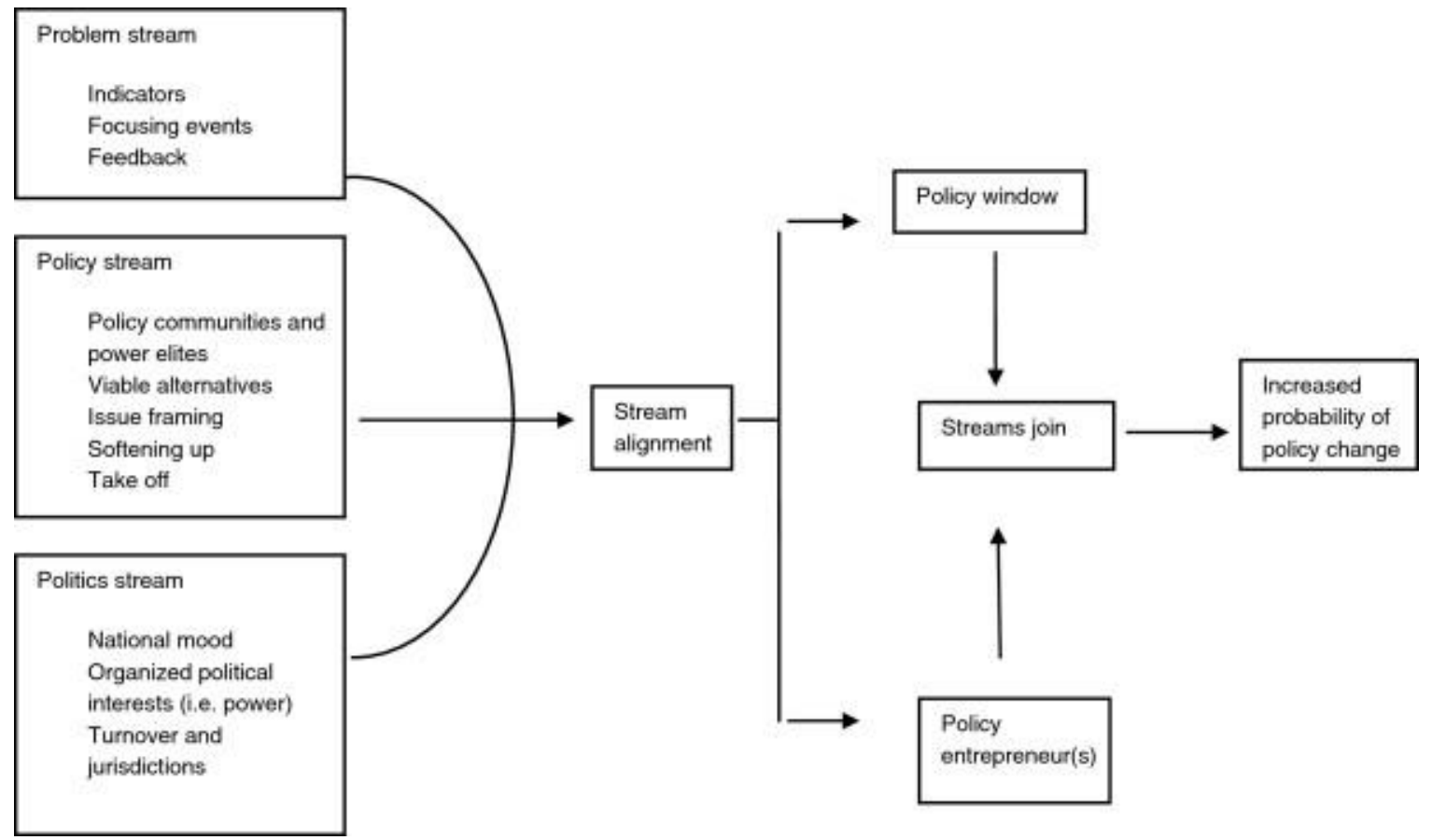

Figure 1: own graph detailing the model based on Kingdon (1983)

\section{Methodology}

This chapter details the methodology of the research. First, the three streams of the model are operationalized. Second, the actors involved in agenda setting are described. Third, an outlook on the sources utilised for the analysis is offered, in order to ensure transparency and replicability.

\subsection{Operationalization: How to Apply the Model in the EU?}

This section operationalises the streams detailed in the theoretical framework by detailing their constitutive elements in this case study and hence provides the necessary context for the analysis section.

The problem stream consists of the means by which officials learn about a problem that is seen as "public" in the sense that government action is needed to resolve it (Béland and Howlett, 2016, p. 222). According to Kingdon (1983), three elements constitute it: first, indicators, which are studies that show that there is a problem. They may take the shape of routine monitoring by governmental and nongovernmental agencies or of specific researches on a particular phenomenon. It is important to notice that it is not the indicators themselves but rather their interpretation that composes the problem stream. Although the interpretation of the indicators is subjective and hence difficult to study, it is usually when the study attests changes or large magnitude of the unit of analysis, that policymakers interpret it as evidence of a problem (p.91). Second, in the problem stream, there are focusing events, which are crises or powerful symbols that draw the attention of the policymakers to conditions. They rarely have permanent effects unless they contribute to indicate the problem more firmly or reinforce a pre-existing perception of it. The notion of focusing events seems to be fitting when dealing with whistleblower laws, which have often arisen in response to scandals, public health scares or environmental disasters (Worth, 2013). For instance, the PIDA English law, known as the strongest 
European legislation on the matter, was passed after a series of costly disasters between 1980 and 1990 among which Britain's worst peacetime maritime disaster, the Herald of Free Enterprise ferry sank, due to a "disease of sloppiness" by the naval company (UK Department of Transport, 1987). Third, the problem stream is also composed of feedback about the operation of existing programs. Feedback brings problems to the attention of policymakers in case the implementation does not square with legislative or higher administrative intent, or stated goals are not attained. However, the notion of feedback does not seem to apply in the case of whistleblowers protection because there has never been any program tackling the issue at a European level, unless in specific sectors like financial services, transport safety and environmental protection.

The problem stream is not only composed of these three elements. It is essential to understand but the way conditions become defined as problems, which happens if conditions violate important values, if they are compared with other countries or if they are placed into a problem category. Likewise, problems can also fade when they become defined as conditions, such as for instance when policymakers think they solved them or if budget constraints occur. Last but not least, the recognition of a problem is not always sufficient to make a subject rise on the policy agenda, but it still seems true, that linking a proposal to a problem that is perceived as real and important, enhances that proposal's prospects for moving up on the agenda (Kingdon, 1983, p.115). At the same, a large part of the responsibility for doing so lies within the policy entrepreneurs, who may highlight indicators or act in a certain way to focus attention on one problem.

By contrast, the political stream is composed of the factors that constitute the broader environment, which act as powerful agenda setters. This stream was originally described by Kingdon (1983) by referring to national mood and elections in the US, and it usually concerns only clearly visible actors (p.199). Considering the peculiarities of EU politics, which are unlike the characteristics of national politics, this stream seems to revolve cyclically around the time of the European elections and the renewal of the EC (Borras and Radaelli, 2011, p. 475). Furthermore, the activity of the lobbies in Brussels and the partisan balance of power in the EP constitute a peculiarity of the EU political stream which must be taken into account (Ackrill et al., 2013).

The policy stream constitutes the way in which policy ideas survive the selection process of the relevant policy community and thus can become solutions to future problems (Kingdon, 2011). Ideas for policies are proposed by "circulating papers, publishing articles, holding hearings, presenting testimony, and drafting and pushing legislative proposals" but while many ideas are being presented, most of them fail to survive the selection process (p. 116). To achieve this, the policy community and particularly policy entrepreneurs are crucial. Policy entrepreneurs are not necessarily part of the policy communities but are invested in their policy ideas, due to personal interests and also because they believe in the rightfulness of their ideas (Kingdon, 2011). Kingdon compares the development of policy to evolutionary selection, in that since public administration does not act quickly and needs time to calculate the political costs and benefits, the subject matter needs to be kept alive through debates, reports, draft bills. In order to survive, policy ideas need to be technically feasible and value conform. This selection process leads to a list of policy ideas, which generates awareness of the problem and causes a bandwagon effect where policy-makers rally behind one idea.

Opportunities for a policy to be implemented are usually slight and rare. An open policy window is an opportunity for advocates to push their solutions or attention to their special problems which are opened by events in either the problem or the political stream. The scarcity and the short duration of the 
opening of a policy window create a powerful magnet for problems and proposals. When a window opens, people concerned with particular problems see the open window as their opportunity to address or even solve these problems, and the open window becomes the opportunity for the complete linkage of problems, proposals and politics. Particularly crucial is the linkage of the solution to either the problem or politics stream, which is usually followed by an attempt to join all three elements, knowing that the chances for enactment of the policy are considerably enhanced if the circle is completed.

\subsection{The Actors: Who is Involved?}

Keeping in mind that within a policy subsystem, actors can be aggregated into advocacy coalitions composed of people from various organizations who act in accordance with each other (Sabatier, 1988), it is relevant to detail the main actors involved in this policy process.

The first inside and evident actor is the EC, who proposed the Directive in the first place. The EC is the EU's executive arm, and it is endowed with the exclusive right of legislative initiative. The EC is divided into departments concerned with specific policy areas, known as Directorates-General (DGs). In this case, although there are different policy areas identified by the different DGs, the concerned one is mainly the DG for Justice and Home Affairs, which is responsible for EU policy on justice, consumer rights and gender equality. This is quite apparent from the text of the Directive, which clearly states that this is the policy area concerned, namely the "lack of effective whistleblower protection can also impair the enforcement of EU law [...] whistleblowing is a means of feeding national and EU enforcement systems with information leading to effective detection, investigation and prosecution in breaches of Union rules" (EC, 2018a, p.1).

In addition, the EP, another inside and evident actor, had pushed intensively for action to be taken. The EP is the only directly-elected institution of the EU, and it acts as a co-legislator with the Council. Although it cannot formally propose legislation, it is often the case that the reports produced by its committees stir the work of the other institutions. For that reason, the contribution of the EP is officially acknowledged in the Directive, which refers to the EP resolution of 24 October 2017 on "Legitimate measures to protect whistleblowers acting in the public interest and its resolution of January 2017 on the role of whistleblowers in the protection of the EU's financial interests" (EC, 2018a). However, the first call to action from the EP dates to 2013, and no acknowledgement of this is present in the Directive. The encouragement from the EP was not limited to the Recommendations on actions and initiatives to be taken (EP, 2013), but also transferred to an Anti-Corruption Pledge signed by 502 MEPs that committed themselves to promote transparency throughout the next EP mandate. Specifically, they assured they would promote "initiatives and legislation that will provide effective protection to whistleblowers in the public, private and non-profit sectors" (TI, 2013, p. 1).

Special attention must be paid to one political group within the EP, namely the Greens and European Free Alliance (Greens/EFA). Although still inside, this actor is less evident than the Parliament as a whole, as it is a small transnational group consisting of the European Greens and of various regionalist parties representing progressive interests. Following the NSA scandal and media storm surrounding Edward Snowden, the Greens/EFA fraction in the EP called for protection of whistleblowers and nominated Snowden for the Sakharov prize, the EU freedom of thought prize (Greens/EFA, 2013). Another key player pushing for harmonised EU legislation on the topic of whistleblower protection was the non-governmental organisation TI. TI was founded 1993 in Germany and functions as an umbrella organisation for numerous national chapters, all focused on combating corruption (TI, n.d.). TI is the 
only outside group which this paper focuses on, because of its extreme significance in pushing whistleblowers' protection on the EP's agenda.

\subsection{Data and Sources}

The main method of this research is document analysis, which allows the application of the theoretical framework as has been detailed in the above section. The primary sources that are analysed are the proposal for the Directive for whistleblowers protection and other official statements issued by the EU (publicly available on their website and/or blogs). In addition, other sources that are employed are publicly available European news outlets, like euronews.com and Euractiv.com. For information on the treatment of international whistleblowers such as Assange and Snowden, international news outlets like the NY Times and The Economist were evaluated. It must be noted that the research is on purpose not limited to a case study of some countries but aims to give a European perspective, which is why the focus was not on the interpretation of national media. This is motivated by the fact that the EC depicts itself as a unitary body, and it does not disclose the different opinions of its individual members, but only communicates its final output as a shared decision of all Member States. For this reason, it would also prove technically very difficult to discern the opinions of the different Member States within the Commission during the negotiations. Nevertheless, some national news outlets like the BBC and L'Espresso are sometimes used to fill the gaps that the European news leaves, but always assuring that they do not reflect any national bias, which should facilitate replicability and allow greater transparency.

\section{Analysis}

This section is devoted to the analysis of the whistleblower Directive according to the Kingdon model. For this reason, it is divided into as many sections as are the parts of the model, namely first the problem stream, second the political stream, third the policy stream and fourth the policy window.

\subsection{Problem stream: Why is there a Problem?}

The problem stream is constituted by indicators and focusing events. Indicators consist of both European and international pushes to the implementation of whistleblowers' protection. Among the European ones, the Directive recalls Council's Recommendation (2014)7 and Resolution 2171 of the Parliamentary Assembly of the Council of Europe ( $\mathrm{COE}$ ). Concerning the international standards to which they refer, the 2004 UNCAC, the G20 Anti-Corruption Action Plan and the OECD Report on "Committing to Effective Whistleblower Protection" are mentioned (United Nations [UN], 2004; OECD, 2016; OECD, 2018). It remains uncertain whether they were all endowed with the same importance by the EC, which seems doubtful, especially considering the relatively old nature of some indicators, such as the UN Convention which dates from 2004. For this reason, not all of them can confidently be seen as having been interpreted as indicators by the EC.

The Directive explicitly recognises the importance of the Second Annual Colloquium on Fundamental Rights (ACFR), held in Brussels on 17-18 November 2016. This event took the shape of a roundtable discussion between institutional, academic, media and civil society representatives on "Media pluralism and democracy". In particular, Session IIb of the meeting dealt with "Whistleblowers and investigative journalism" (EC, 2016b), and consisted of a discussion around the legal gaps on the protection of whistleblowers against retaliation. The participants in particular expressed concern for the 
impact that surveillance on journalists' communications has on privacy and safety of reporters. They suggested to learn how to train journalists to use technology in order to be able to communicate while protecting their privacy and creating mechanisms to enable anonymous whistleblowing (EC, 2016b, p.1). During the discussion, several studies were mentioned to function as a basis to assess the magnitude of the problem, such as the 2013 report of TI (Worth, 2013). In the report it is stated that only four EU countries had, at the time of writing, advanced legal frameworks to protect whistleblowers, which means they included "comprehensive or near-comprehensive provisions or whistleblowers who work in the private and/or public sector" (Worth, 2013, p. 9) and among those who have partial protection, several were deemed to contain loopholes, which delivers a discouraging picture of lacking political will to ensure whistleblowers' protection (Worth, 2013, p. 5).

The outcome of the Colloquium was stated by the EU Justice Commissioner Věra Jourová to be the launch of

a broad public consultation inviting the input of all relevant stakeholders on what EU level can do to strengthen the protection of whistleblowers. We are looking at different options - this doesn't mean it will be the Directive you are calling for, but we want to find the best solution (EC, 2016a).

This was deemed to be relevant in light of the Eurobarometer 2017 , to which $80 \%$ of the respondents replied that they did not report corruption they had experienced (EC, 2017a, p. 96) and three quarters of the respondents mentioned lack of protection for those who report corruption as a factor motivating the choice (p.101), an answer that did not significantly change since the last survey. The Directive explicitly recognised the Eurobarometer as an indicator of the magnitude that underreporting whistleblowers can have, together with the results of its public consultation and an economic study mandated by the EC that estimated the monetary loss from a lack of whistleblowers protection to be between EUR 5.8 and EUR 9.6 billion every year in public procurement alone (EC, 2017b; McGuinn, Rossi and Fernandes, 2017). In addition to these, the Colloquium itself seems to have represented an event where relevant indicators became known to the Commission, although the focus of it was exclusively on whistleblowing in journalism. The conclusion drawn from these indicators is that there is a strong case, not least an economic one, for regulating whistleblowers protection at the EU level.

At the same time, the Directive recounts other actors for having determined the rise of the problem to the attention of the EC, namely the Council with its Conclusions on tax transparency of 11 October 2016, together with civil society organizations and trade unions. The most explicit of these contributions seems to be that of TI, which namely called the European Union to "submit a legislative proposal establishing an effective and comprehensive European Whistleblower Protection Programme in the public and private sectors" (Worth, 2013, p.22). In doing so it also directly quotes the EP's call for action that had already been submitted in 2013, which indeed focused on the improvement of whistleblowers protection especially in the area of journalism (EP, 2013). It had also established internationally accepted guidelines to strengthen whistleblower protection in countries that had signed the UNCAC. This hints at TI's character of policy entrepreneur because they seem to have pushed for increased whistleblowers protection and to have also been those who influenced the EP in the first place.

Regarding focusing events, the EU was clearly influenced in passing this legislation by international scandals such as the Snowden revelations, which had enormous political importance everywhere in the world. However, to identify specific causations is challenging. The Snowden 
revelations seem to have had resonance within the EU in light of the EP's Committee on Civil Liberties report issued on 21 February 2014 which contained a motion for an "EP Resolution on the US NSA surveillance programme [...] and its impact on EU citizens' fundamental rights" (EP, 2014a). The report wishes to draw the attention to the fact that the lack thereof brings a "chilling effect on media" and on whistleblowers, which should have the crucial role to ensure democratic accountability and whose freedom to act is not protected enough in this surveillance society. Hence, the Snowden affair was used to highlight the gravity of the problem, which had persisted since 2013, when the first call to action had been voiced.

By contrast, different news outlets argued that diverse scandals had the role of focusing events. Although it is argued in the next chapter that the LuxLeaks scandal had special importance for the development of the events, it did not seem to work as a proper focusing event. Nevertheless, one should not forget to acknowledge evens such as LuxLeaks, the Panama Papers and the Cambridge Analytica scandals, that shone a light on the condition of whistleblowers and pushed the EP to push for increased protection (Dalby and Bowers, 2019). In conclusion, despite the Directive acknowledging several European and international guidelines for the protection of whistleblowers, the ACFR seems to have been the crucial event where indicators such as the estimation of the economic benefits of whistleblower protection in public procurement, the Eurobarometer 2017 and its public consultation, became known to policy-makers, albeit in the field of journalism. The Snowden revelations seem to have corroborated the idea of a pre-existing problem, which had become known in 2013 after the call to action from the EP. The following section investigates the reasons why action was not taken expeditiously.

\subsection{Political stream: How is the Political Atmosphere?}

This section deals with the political stream in a chronological way (for a clear overview of the timeline refer to Annex 1). A first observation is that the EC had rejected the 2013 call for action from the EP with the argument that it was only willing to include a provision for internal whistleblowing (Nielsen, 2013). The reasons for this are the crucial focus of this section. The most relevant political event that occurred in the chosen time frame were the European elections leading to the election of the Juncker Commission as a successor after the Barroso II Commission. This means that the first call to action in 2013 was directed to the outgoing Commission, which was substituted merely 6 months after having received the invitation to act. One could deduce that the outgoing Commission did not have enough time to start this legislative proposal, which is reasonable enough when realising that not only would they have had to draft it but also to have it voted by the EP and the Council to make sure it passed. Thus, it is rational to hypothesise that the feasible responsibility to provide for whistleblowers protection fell on the Juncker Commission. However, the latter did not act promptly and waited until 2018 to take up the proposal of the EP. This is puzzling especially considering that among Juncker's priorities, number 7 was "an area of justice and fundamental rights based on mutual trust". Although not explicitly mentioning the protection of whistleblowers as an objective, this priority does refer to the policy area that covers whistleblowers protection (EP, 2014b). Hence, the question one now needs to ask is how was the Juncker Commission convinced to insert whistleblowers protection on the agenda?

In November 2014, the LuxLeaks scandal emerged and personally involved the then-President of the EC, Jean-Claude Juncker. Luxleaks concerned the leak by the International Consortium of Investigative Journalists of an archive of 28000 documents provided by two employees of PriceWaterhouseCoopers (PWC), Antoine Deltour and Raphaël Halet (Barbière, 2017). These revealed 
secret agreements known as "tax rulings" between 340 multinational corporations, including PepsiCo INC and Deutsche Bank AG, and Luxembourg, which allowed the former to pay less than $1 \%$ taxes in Luxembourg (Bowers, 2019b). The conclusion drawn from these leaks was that Luxembourg was a major European centre of corporate tax avoidance (Biondani and Sisti, 2018). There were calls to the then-new competition Commissioner Margrethe Vestager to act, but she declined immediate action and instead stated that the Commission considered the Luxleaks documents as "market information" and hoped they would lead to a common consolidated corporate tax base being supported throughout the EU (Bowers, 2019a; Jacobsen, 2014).

The Luxleaks scandal was an uncomfortable occurrence for the then-new Commission President Jean-Claude Juncker who had served as Prime Minister of Luxembourg from 1995 to 2013 and as its Minister for Finances from 1989 to 2009. It was calculated that only between 2002 and 2010, his country had received 220 billion dollars through the uncovered illicit tax avoidance practices (Biondani and Sisti, 2018), thereby implicitly presuming his involvement. At first not releasing any comments on the leak, Juncker soon defended the tax practices in Luxembourg saying they were "normal practices in 22 MS and conform with EU law, provided that the benefits are applied in a non-discriminatory manner" (Jacobsen, 2014). Although admitting having played an active role in courting multinational corporations, he always stated to have done so in respect of fiscal law and stated to be offended by the accusations (Bowers, 2019a). Nevertheless, a following wave of scepticism on Junker's fitness to work in the interest of Europe caused the right wing Eurogroup in the EP to start a petition for a no-confidence vote, after a similar initiative by the left-wing groups had failed. However, Junker comfortably survived the no-confidence vote as the European People's Party and the Socialists \& Democrats did not support it (Biondani and Sisti, 2018).

It is important, because of the focus of this research, to investigate what happened to the whistleblowers of the Luxleaks issue, as it is an indication of the level of whistleblower protection in place and the extent to which the Commission reacted to it. Deltour tried to fit the criteria of the Trade Secrets Directive, which had at the time not yet been implemented by the Luxembourgish government. The Trade Secrets Directive states in paragraph 20 that "the measures, procedures and remedies provided for in this Directive should not restrict whistleblowing activity [...] [and] should not extend to cases in which disclosure of a trade secret serves the public interest" (EP and Council of the EU, 2016). However, he was not recognised to fit them, which revealed the inadequacy of EU law to cover whistleblowers protection. He was however recognised as a whistleblower by Luxembourg's highest court and therefore acquitted. The same treatment was granted to Edouard Perrin, the journalist that published the information. This was not the case for the other PWC employee who had blown the whistle, namely Halet, who received a 1000 euro fine after judgement from the same Court ("Luxleaks whistleblower Antoine", 2018). Verstager said in a 2016 interview that "everyone should thank both the whistleblower and the investigative journalists" (Valero, 2016). This shows that the whsitleblowers involved in the Luxleaks scandal did not receive adequate protection, much less so from EU law.

This was not the end for Junker, who was also called to testify in an investigation on the Panama Papers on May 30, 2017. The Panama Papers scandal involved the leaking of two and a half terabytes of leaked data on legal and illegal transactions made by heads of governments, drug dealers and banks that all used Panama as their offshore financial heaven (Gotev, 2017). Junker was asked to appear in front of an investigative committee, tasked with understanding if breaches of EU law had occurred as a consequence of the leaked activities. He was investigated because the new leaks still 
concerned the Luxleaks, and he was found to again not have committed any irregularity. He restated that the credibility of the Commission should have been measured by the work of the Commission and not been based on the work carried out in the name of one country's government ("Panama Papers: Juncker", 2017). As a reaction, one may believe that Juncker had desired to work intensively on reducing corporate tax evasion at the EU level to show his disfavour towards these illicit practices (Bassot and Hiller, 2018, p. 16).

\subsection{Policy stream: Development of the EU whistleblower policy}

The policy stream examines the survival and development of policy ideas, which may be solutions for a problem not yet acknowledged by policy-makers but of importance to policy entrepreneurs, who invest time and resources in them. As the chapter on the problem stream demonstrated, various studies have been published with regards to whistleblower protection, which is important because while presenting the problem they also often offer policy ideas.

Whistleblower protection is mentioned as a necessity in Chapter III Art. 33 of the UNCAC, which was signed in 2003 by the EU. The achievement status of the UNCAC is evaluated by the Implementation Review Group (IRG), which meets at least once a year in Vienna, where the UN Office on Drugs and Crime is situated. In May 2013, the IRG met to discuss the implementation status of Chapter III and discussed a submission by TI which proposed international principles for whistleblower legislation in countries that had signed the UNCAC (Heimann, Dell and Bathory, 2013). TI presented their findings during a panel discussion and recommended more detailed country reports about the implementation as well as an observer status for NGOs who can provide technical assistance. The IRG followed this call and urged UNCAC Member States to take further action in order to enhance and harmonise whistleblower legislation (Implementation Review Group of the United Nations Convention against Corruption, 2013). They voiced the need for anonymous reporting available to citizens as well as for protection in "labour and administrative laws" (Heimann et al., 2013, p. 12).

This call was heard by the EP, which called on the EC to propose enhanced legislation to protect both private and public whistleblowers in its October 2013 Resolution on organised crime and money laundering (EP, 2013). It requested "effective and comprehensive legislation" to be proposed before the end of 2013, which included a whistleblower protection programme, particularly for cases of financial corruption. Nevertheless, the policy ideas were not yet defined, and it was TI which started developing clear policy ideas by publishing an assessment report on the level of legislative protection for whistleblowing in the EU Member States, identifying political, economic and social issues able to hinder whistleblowing (Worth, 2013). They urge the Commission to listen to the EP and again requested more consultation with civil society organisations (p.22). Furthermore, TI called for "accessible, reliable and safe channels to report wrongdoing", protection from retaliation as well as mechanisms to translate the reporting into reforms of inadequate policies and behaviours for both public and private employees ( $p$. 22). They gave a rather broad definition of those employees including also volunteers, interns and former employees and listed various disclosures that need to be protected besides the obvious miscarriage of justice such as dangers to public health and environment and also mismanagement. Interestingly, TI urged the EC to follow the 2013 call by the EP for legislation and mentioned internal whistleblower protection for the EU institutions.

Indeed, starting in January 2014 all EU institutions were required to implement their own whistleblowing rules. In her initial inquiry, the European Ombudsman, Emily O'Reilly, requested 
information regarding the progress of adopting the internal rules. The Commission replied that they already adopted binding guidelines in 2012 and that they "consulted two external organisations with expert knowledge and had also held discussions with staff representatives" (O'Reilly, 2015). Ending the inquiry in February 2015, the European Ombudsman discovered that most EU institutions, amongst them the Commission, had failed to implement the requested rules. The internal protection for whistleblowers is based on the EU Staff Regulations and requires the whisleblowers, unlike in the UNCAC and TI, to turn to their supervisor or the European Anti-Fraud Office, thus not allowing for anonymous reporting.

In the wake of the NSA scandal and Snowden's revelation, the EP issued another report in February 2014 on the US surveillance of the EU Member States and the impact on citizen's rights. Again, the report calls on the Commission to look into comprehensive EU-wide whistleblower protection, this time including journalists, and also mentions the potential expansion of the protection to other EU competences, particularly mentioning the field of intelligence (EP, 2014b). The report also calls on Member States to ensure that national legislation allows for disclosure of "corruption, criminal offences, breaches of a legal obligation, miscarriages of justice and abuse of authority", but unlike the TI report from 2013 does not include dangers to public safety and environment. The report was accompanied by an explanatory statement, describing the public debate on mass surveillance and reasons why the EU should or should not act. It also lists the five reasons for the EU not to act on whistleblower protection, which are: lack of competence, since national intelligence and security are national competence; potential danger of informing terrorist groups if leaked documents are investigated; lack of legitimacy for the whistleblower; the need for a working relationship between the EU and the US; the presumption of good governments that act with democratic standards as a matter of principle. As can be seen, these are various strong arguments to be made against EU-wide legislation to protect reporting persons and a potential lack of ability due to missing legal basis (EP, 2014b), which partly help to explain the delay in passing the Directive.

Soon after the aforementioned EU report, potential legislation ideas to protect whistleblowers again came to the attention in Brussels. The Council of Europe, an international organisation aiming at promoting human rights, which includes the EU Member States but also other European states as well as Russia, published a recommendation for legislation to protect whistleblowing in the public and private sphere in April 2014. This aimed predominantly at achieving greater legal unity in the 47 Member States, and that is why the recommendation includes clear policy principles to guide the drafting of legislation (Council of Europe, 2014). This policy picked up the ideas of the TI 2013 report, including interns, volunteers and former as well as prospective employees in both the public and private sector. Moreover, they defined the channels of reporting mentioned by TI: allowing for internal reports within the organisations, reports to supervisory bodies and last also to the public. These channels strongly resemble the ones in the PIDA English legislation for the protection of whistleblowers, and since the UK is a member in the Council, it is likely that their model for reporting channels was overtaken. Also, they maintained the principle of anonymous reporting from the UNCAC and TI 2013 report. Altogether, the policy recommendation of the Council of Europe (COE) adopts most ideas of the TI 2013 report, thus allowing them to survive for a longer period (CoE, 2014).

TI continued to publish reports about citizen's approval of whistleblowers in 2015 (Gorbanova, 2015). Following a period without new policy proposals, the Greens/EFA group in the EP sent a letter to Commission president Juncker in May 2016. Stating that the EP had been calling for legislation over the 
past decade while the Commission had remained inactive, the Greens/EFA presented a draft Directive for whistleblower protection across Europe, thus bypassing the EC as policy initiator (Greens/EFA, $2016 a$ ). In the draft Directive, "recent evaluations of the status of whistleblower protection" are mentioned as a reason to act, hinting at the reports by TI. The Directive proposal also presents several legal bases, which are necessary for any EU legislative action, and that the Commission used to defend its inaction by claiming whistleblower legislation was outside of the EU's competences (Reda, April 23 2018). Moreover, even the title of the Greens/EFA Directive announces both private and public employees to be included, including former workers and volunteers. Similarly to the CoE policy recommendation, they included various channels of reporting, including social media. In their list of potential disclosures that should be protected under the Directive, the Greens/EFA also incorporate prospective harms to the public interest. Their Directive would also encompass "honest mistake" reporting and like the TI policy recommendation would allow the identity of the reporting persons to be confidential (Greens/EFA, $2016 \mathrm{~b})$. The principle of full protection in case of error had survived since the TI report and the CoE recommendation which mentions that protection "should not be lost solely on the basis that the individual making the report or disclosure was mistaken" (CoE, 2014).

In February 2017 the EP adopted a resolution on "Legitimate measures to protect whistleblowers acting in the public interest", where it again called for a horizontal legislative proposal. The Committee on Legal Affairs (JURI) followed this up in October 2017 with an own-initiative report on legislative measures protecting whistleblowers, calling for adopting current international standards. The report also voices the need for a broad definition of "whistleblower" to "cover as many scenarios as possible" (again both private and public sector employees) and the creation of an EU agency to coordinate the reports of whistleblowers (EP, 2019). JURI also aims to broaden the range of to be disclosed acts, including all breaches in the public interests, thus including the request of the TI 2013 report for broad lists of disclosures. They stress that anonymous reporting could encourage the sharing of information otherwise kept secret and cover whistleblowers in honest mistake (EP, 2017).

Finally, on 23 April 2018, the Commission proposed an EU-wide Directive to protect whistleblowers. Julia Reda, a member of the Greens/EFA, the group that proposed the draft Directive already in 2016, claimed that the final Commission proposal included many key points of their draft (Reda, 2019). The two proposals share major principles; however, the Commission proposal holds the Council of Europe recommendation of 2014 as part of the framework in their final proposal and also refers to the work of TI (EC, 2018a). The overall reluctance of the Commission regarding whistleblower protection can be seen in the choice of the legal instrument to be a directive, which constitutes the least intrusive legal instrument the EU can make use of. This is because it sets minimum targets to implement by the Member States but leaves the means to do so to their own discretion. This further corroborates the idea that despite the survival of policy ideas, the implementation of the latter proved difficult and the Member States were somewhat reluctant. In conclusion, the existence of different solutions emerging at different points in time has been shown, and some in-depth analysis devoted to the ideas that survived throughout the years. However, this alone cannot account for the relation between them all.

\subsection{Wrapping it all up: the policy window}

The policy window examines how a particular stream can constrain or instigate agenda setting, offering an opportunity for the streams to come together at a particular time when a pressing problem is linked to an existing policy solution. Evaluating the problem, political and policy stream reveals that the 
window opened in the political stream, causing the specific timing that put whistleblower protection on the agenda of the EC. In general, studies promoting the need for whistleblower protection as well as scandals to focus the policy-maker's attention were continuously present, just like the ideas for a policy to protect whistleblowing, which however became more defined throughout the years. TI, persistently put it on the agenda of the EP, and caused the first call to action being issued by the EP in 2013 . Because of the survival of TI's ideas, TI is acknowledged to be the primary policy entrepreneur around this issue. At this time when the first call for action was issued, the main area concerned by the provision was journalism, as main indicators such as the study "Estimating the economic benefits of whistleblower protection in public procurement" were made public at the ACFR's session on investigative journalism. Thanks to the focusing event of the Snowden Revelations, the attention of the EP was kept on the issue, and led to the production of the EP Resolution on the US NSA surveillance, which was the instance when the EP proposed that the whistleblower programme would extend to areas other than journalism, including intelligence. At this point, the Luxleaks scandal personally involved Jean-Claude Juncker, the head of the EC, and stalled the procedures for implementation of the whistleblowers protection programme because the DG Justice and Home Affairs of the EC could not propose the policy without further compromising its President, who was also called to testify in 2017 for potential involvement in the Panama Papers leak. While the scandals delayed the adoption of a policy, the development of policy ideas on the one hand slowed down. On the other hand, some ideas survived and may have benefitted from a "calmer" period to stabilise in the minds of policymakers. Supported by the $\mathrm{CoE}$, which basically reintroduced the same ideas of the 2013 TI report, the Greens/EFA took the courage to become in their turn policy entrepreneurs and proposed a draft Directive in 2016. Then, the decision to pass an EU law to protect whistleblowers on 30 May 2017 was when the political scenario had turned favourable for Juncker, on behalf of the EC, to pass the legislation containing policy ideas that had survived the selection process of the policy stream, namely the ideas that had been present since the first TI report, such as the protection of whistleblowers in both the private and public sphere and the safeguarding of reporters also in cases of honest mistakes. The streams came together in 2018, which also coincided with the Facebook-Cambridge Analytica data scandal and thus allowed the EU to seem to take immediate action with regards to it. The existence of a policy window is confirmed by the way the EP voted for the Directive: 591 votes in favour, 29 against and 33 abstentions. The large majority of favourable opinions confirms that the context was finally, in 2018, favourable to the coupling of the Greens/EFA's draft legislation to the problem of whistleblowing protection.

\section{Conclusion}

While this paper is being written in June 2019, Julian Assange is sitting in Her Majesty's Prison Belmarsh in London, charged with 17 counts of violating the 1917 US Espionage Act, which add to his prior hacking-related charges brought by Northern Virginia. An official of the Justice Department's National Security Division said that the US government "takes seriously the role of journalists in our democracy and [...] It is not and has never been the department's policy to target them for reporting" but argues that Assange is not a journalist (Savage, 2019 May 23). Exactly such roundabout argumentation to imprison whistleblowers for their reporting and thereby discouraging further whistleblowing is the reason behind the proposal of an EU Whistleblower Protection Directive.

Freedom of expression and reporting is essential for any democracy and is also enshrined in the EU Charter of Fundamental Rights. Fragmented legislation between EU Member States alone would 
usually lead to Commission action in order to allow a smooth and effective working of EU policies. However, in this case it took 5 years for the initial call to be followed by action by the EP on the final proposal. Such a time gap is unusual, in particular when one recounts the media attention given to the issue due to various scandals such as the Lux Leaks and the Snowden affair. This research analysed the reasons why whistleblower protection only rose to the agenda of the EC in 2018. In order to do so, we first examined the academic literature regarding whistleblower protection in the EU, showing that the legal landscape was far from harmonised, thus offering a chance for the EC to act. Using the Kingdon model to independently analyse the problem, politics and policy stream allowed for an in-depth investigation of the development of the policy window. The analysis reveals that lacking whistleblower protection was perceived as a problem through the entire time frame due to various studies and scandals to grab the attention of policy-makers. Policy ideas for the final legislation existed since the early 2010s following the Snowden Scandal and survived thanks to the efforts of the EP, particularly the Greens/EFA as well as TI. Thus, leaving the politics stream to prevent an earlier proposal, the research demonstrates that the involvement of the then newly-elected Commission president Juncker in the Lux Leaks and the following Panama Papers scandal caused the proposal to be delayed. The proposal of the Directive "on the protection of persons reporting on breaches of Union law" in April 2018 coincided with the Cambridge Analytica scandal, presenting the EC with an appropriate moment to react

By selecting this theory, however, this thesis also adopts the limitations inherent in it such as the assumption that the convergence of the streams inevitably leads to a policy window. Another limitation is that the model has explanatory but no predictive power. It helps understand why the policy change occurred, but it would not have allowed, when applied to the facts preceding the proposal of the Directive, to anticipate it. Other authors have tried to modify it to the extent that it would gain predictive power. Although for the purposes of this paper this has not been deemed to be necessary because the objective was mainly to uncover the dynamics that delayed a swift reaction to the calls from the EP from the EC.

On a more general note, due to the confidentiality of the internal workings of the EC, it is challenging to retrace the exact steps taken in the development of the Directive. Instead, this research is only offering a possible explanation on why the EC decided to propose the legislation in 2018 based on observable events without an actual insight into the responsible Commission DG Justice. Hence, it could be argued that this research is biased towards events that have been cherry-picked for the problem, political or policy stream and thus the development of the examined legislation. Since the Commission proposal named the context of the legislation as well as results from stakeholder consultation, the research followed the given references and thereby attempted to nuance the inherent selection bias. Moreover, without making such educated guesses on the internal workings of the EU Commission and EU policy-making in general, no academic research could be done due to the culture of confidentiality prevalent in Brussels. To present a more substantiated picture, further research could aim to gain a behind-the-scenes look by interviewing members of the concerned Directorate-General Justice. This paper decided against such a rather individual approach and is instead interested in the chains of events enabling issues to rise to the agenda and thereby providing a more overarching picture, which shows that this policy proposal was not straightforward but required a long time. Due to the confidentiality and the "Brussels Bubble", EU policies often seem nebulous, therefore making it important to see how legislation develops and crucial to discover if EU institutions are preventing policy making in public interests due to external factors. Further research could corroborate (or disprove) these findings by

\section{Research Papers}


conducting a policy-analysis of the implementation of the same Directive and verifying the Member States' attitude towards the problem. 


\section{Reference List}

"What is WikiLeaks" (2015, 3 November). Retrieved from https://wikileaks.org/What-is-WikiLeaks.html.

Ackrill, R., and Kay, A. (2011). Multiple streams in EU policy-making: the case of the 2005 sugar reform. Journal of European public policy, 18(1), 72-89.

Ackrill, R., Kay, A., and Zahariadis, N. (2013). Ambiguity, multiple streams, and EU policy. Journal of European Public Policy, 20(6), 871-887.

Barbière, C. (2017, 1 June). Juncker promises EU law to protect whistleblowers. Euractiv. Retrieved from https://www.euractiv.com/section/economy-jobs/news/juncker-promises-eu-law-to-protectwhistleblowers/

Barzelay, M. and Gallego, R. (2006). From "new institutionalism" to "institutional processualism": advancing knowledge about public management policy change. Governance, 19(4), 531-557.

Bassot, E., and Hiller, W. (2018). The Juncker Commission's ten priorities: State of play in autumn 2018 [Study]. Retrieved from http://www.europarl.europa.eu/RegData/etudes/STUD/2018/625176/EPRS_STU(2018)625176_ EN.pdf

Béland, D., and Howlett, M. (2016). The role and impact of the multiple-streams approach in comparative policy analysis. Journal of Comparative Policy Analysis, 18(3), 221-227.

Biondani, P., and Sisti, L. (2018, 30 October). Così Jean-Claude Juncker ha ucciso il sogno dell'Europa. L'Espresso. Retrieved from http://espresso.repubblica.it/plus/articoli/2018/10/29/news/junckerkiller-d-europa-1.328139

Borrás, S., and Radaelli, C. M. (2011). The politics of governance architectures: creation, change and effects of the EU Lisbon Strategy. Journal of European Public Policy, 18(4), 463-484.

Börzel, T. A., Stahn, A. and Pamuk, Y. (2010). The European Union and the fight against corruption in its near abroad: can it make a difference?, Global Crime, 11(2), 122-144.

Bouville, M. (2008). Whistle-blowing and morality. Journal of Business Ethics, 81(3), 579-585.

Bowers, S. (2019a, 7 March). European Authorities Launch Probe Into Secret Lux Leaks Tax Deal. International Consortium of Investigative Journalists. Retrieved from https://www.icij.org/investigations/luxembourg-leaks/european-authorities-launch-probe-intosecret-lux-leaks-tax-deal/

Bowers, S. (2019b, 12 February). Why has the European Commission not investigated Lux Leaks tax deals?. International Consortium of Investigative Journalists. Retrieved from https://www.icij.org/investigations/luxembourg-leaks/why-has-the-european-commission-notinvestigated-lux-leaks-tax-deals/

Callahan, E. S., Dworkin, T. M., and Lewis, D. (2003). Whistleblowing: Australian, UK, and US Approaches to disclosure in the public interest. Virginia Journal of International Law, 44(3), 879912.

Coney, P., and Coney, C. (2016). The Whistleblower Protection Act (Japan) 2004: a critical and comparative analysis of corporate malfeasance in Japan. Monash University Law Review, 42(1), 41-71.

Council of Europe (2014). Recommendation CM/Rec(2014)7 of the Committee of Ministers to Member States on the protection of whistleblowers [Recommendation]. Retrieved from https://search.coe.int/cm/Pages/result_details.aspx?ObjectID=09000016805c5ea5

Da Silva Marques, J. V. (2019, 18 April). Whistleblowers across Europe now have more protection, but Assange divides opinion. Euronews. Retrieved from https://www.euronews.com/2019/04/17/whistleblowers-across-europe-now-have-moreprotection-but-assange-divides-opinion

Dalby, D., and Bowers, S. (2019, 18 April). Lux Leaks, Panama Papers spur EU to better protect whistleblowers. International Consortium of Investigative Journalists. Retrieved from: https://www.icij.org/investigations/panama-papers/lux-leaks-panama-papers-spur-eu-tobetter-protect-whistleblowers/

European Commission (2016a). Closing remarks of the second Fundamental Rights Colloquium on Media Pluralism and Democracy by Commissioner Věra Jourová. [Speech]. Retrieved from http://europa.eu/rapid/press-release_SPEECH-16-3842_en.htm

European Commission (2016b). Session IIb: Whistle-blowers and investigative journalism. Retrieved from http://ec.europa.eu/information_society/newsroom/image/document/2016-45/20161031134140_session_ii_b_docx_19251.pdf

European Commission (2017a). Special Eurobarometer 470. Retrieved from http://ec.europa.eu/commfrontoffice/publicopinion/index.cfm/Survey/getSurveyDetail/yearFrom /2017/yearTo/2017/surveyKy/2176. 
European Commission (2017b). Public consultation on whistleblower protection. Retrieved from https://ec.europa.eu/newsroom/just/item-detail.cfm?item_id=54254.

European Commission (2018a, April 23). Proposal for a Directive of the European Parliament and of the Council on the protection of persons reporting on breaches of Union law [Legislative proposal $n$. COM/2018/218]. Retrieved from https://eur-lex.europa.eu/legalcontent/EN/TXT/?uri=CELEX:52018PC0218

European Commission (2018b). Summary results of the public consultation on whistleblower protection. Retrieved from https://ec.europa.eu/info/sites/info/files/annex_13.pdf

European Commission (2018c). Whistleblower protection: Commission sets new, EU-wide rules [Press release]. Retrieved from http://europa.eu/rapid/press-release_IP-18-3441_en.htm

European Parliament (2013). Resolution of 23 October 2013 on organised crime, corruption and money laundering: recommendations on action and initiatives to be taken (Report n.2013/2107(INI)). Retrieved from http://www.europarl.europa.eu/sides/getDoc.do?type=TA\&reference=P7-TA2013-0444\&language $=\mathrm{EN}$

European Parliament (2014a). Report on the US NSA surveillance programme, surveillance bodies in various Member States and their impact on EU citizens' fundamental rights and on transatlantic cooperation in Justice and Home Affairs. (Report n. 2013/2188(INI)). Retrieved from https://www.europarl.europa.eu/sides/getDoc.do?pubRef=-//EP//TEXT+REPORT+A7-2014$0139+0+\mathrm{DOC}+\mathrm{XML}+\mathrm{V} 0 / / \mathrm{EN}$

European Parliament (2014b). Setting EU priorities, 2014-19: The ten points of Jean-Claude Juncker's political guideline [Briefing paper n. PE 538.963]. Retrieved from: http://www.europarl.europa.eu/EPRS/EPRS-Briefing-538963-Setting-EU-Priorities-2014-19FINAL.pdf/

European Parliament (2017). Report on legitimate measures to protect whistle-blowers acting in the public interest when disclosing the confidential information of companies and public bodies [Report n. A8-0295/2017]. Retrieved from http://www.europarl.europa.eu/doceo/document/A8-2017-0295_EN.html?redirect

European Parliament and Council of the European Union. (2016, June 8). Directive EU 2016/943 on the protection of undisclosed know-how and business information (trade secrets) against their unlawful acquisition, use and disclosure, Official Journal of the European Union, 15.6.2016, L 157/1-18.

Follesdal, A., and Hix, S. (2006). Why there is a democratic deficit in the EU: A response to Majone and Moravcsik. Journal of Common Market Studies, 44(3), 533-562.

Glazer, M. P. and Glazer, P. M. (1989). The Whistleblowers: Exposing Corruption in Government and Industry. New York: Basic Books.

Gorbanova, M. (2015). Speak Up - Empowering citizens against corruption. Retrieved from: https://www.transparency.org/whatwedo/publication/speak_up_empowering_citizens_against_c orruption

Gotev, G. (2017, 2 February). Greens slam Commission for blocking Panama Papers probe. Euractiv. Retrieved from https://www.euractiv.com/section/euro-finance/news/greens-slam-commissionfor-blocking-the-panama-papers-probe/

Grant, C. (2002). Whistle Blowers: Saints of Secular Culture. Journal of Business Ethics, 39(4), 391399.

Greens/EFA (2013, September 30). Sakharov Prize - Edward Snowden makes shortlist for EU freedom of thought prize after Green nomination [Press release]. Retrieved from https://www.greensefa.eu/en/article/press/sakharov-prize-4810/

Greens/EFA (2016a, May 3). Letter presenting you with a draft Directive to protect whistle-blowers across Europe. Retrieved from: https://www.greensefa.eu/legacy/fileadmin/dam/Images/Transparency_campaign/Letter_to_Juncker_on_whistleblo wing_directive_sent_3_May_2016.pdf

Greens/EFA (2016b, May 4). Whistleblower Protection in the public and private sector in the European Union: A draft directive. Retrieved from https://www.greensefa.eu/legacy/fileadmin/dam/Images/Transparency_campaign/WB_directive_draft_for_consultat ion_launch_May_2016.pdf

Gunsalus, C. K. (1998). How to Blow the Whistle and Still have a Career Afterwards. Science and Engineering Ethics, 4(1), 51-64.

Haas, E.B. (1968). The Uniting of Europe: Political, Social, and Economic Forces 1950-1957. Stanford, CA: Stanford University Press.

Heimann, F., Dell, G. and Bathory, G. (2013). UN Convention Progress Report 2013. Retrieved from: https://www.transparency.org/whatwedo/publication/un_convention_against_corruption_progre ss_report_2013

Howard, C. (2005). The policy cycle: a model of post-Machiavellian policy making?. Australian Journal of Public Administration, 64(3), 3-13. 
Jacobsen, H. (2014, 21 November). Vestager says will use 'Luxleaks' documents in EU tax probe. Euractiv. Retrieved from https://www.euractiv.com/section/competition/news/vestager-sayswill-use-luxleaks-documents-in-eu-tax-probe/

Jos, P. H., Tompkins, M. E., and Hays, S. W. (1989). In praise of difficult people: A portrait of the committed whistleblower. Public Administration Review, 49(6), 552-561.

Jubb, P. B. (1999). Whistleblowing: A restrictive definition and interpretation. Journal of Business Ethics, 21(1), 77-94.

Julian Assange in the Ecuadorian embassy: Timeline (2019, May 23), BBC. Retrieved from https://www.bbc.com/news/world-europe-11949341.

Julian Assange: journalistic hero or enemy agent?. (2019, April 12), The Economist. Retrieved from https://www.economist.com/britain/2019/04/12/julian-assange-journalistic-hero-or-enemyagent.

Kingdon, J. W. (1983). Agendas, alternatives, and public policies, with an epilogue on health care, 2nd ed., Harlow: Pearson Education Inc.

Kingdon, J.W. (2011). Agendas, alternatives and public policies, 2nd edn. Boston, MA: Longman.

Larmer, R. A. (1992). Whistleblowing and employee loyalty. Journal of Business Ethics, 11(2), 125-128.

Luxleaks whistleblower Antoine Deltour has conviction quashed (2018, 11 January), BBC News. Retrieved from https://www.bbc.com/news/world-europe-42652161

McGuinn, J., Rossi, L., and Fernandes, M. (2017). Estimating the economic benefits of whistleblower protection in public procurement (Report n. ET-01-17-799-EN-N). Retrieved from https://publications.europa.eu/en/publication-detail/-/publication/8d5955bd-9378-11e7-b92d01 aa75ed71a1/language-en.

Natali, D. (2004). Europeanization, policy arenas, and creative opportunism: the politics of welfare state reforms in Italy. Journal of European Public Policy, 11(6), 1077-1095.

Nielsen, N. (2013, October 23). EU-wide whistleblower protection law rejected. EU Observer. Retrieved from https://euobserver.com/justice/121873

Nyreröd, T., and Spagnolo, G. (2018, May 28). A proposed EU Directive on whistleblower protection [Blog post]. Retrieved from https://voxeu.org/article/proposed-eu-Directive-whistleblowerprotection

O'Reilly, E. (2015). Decision of the European Ombudsman closing her own-initiative inquiry OI/1/2014/PMC concerning whistleblowing [Case n. OI/1/2014/PMC]. Retrieved from https://www.ombudsman.europa.eu/en/decision/en/59114\#_ftn1

Organisation for Economic Co-operation and Development (2016). Committing to Effective Whistleblower Protection. Paris: OECD Publishing. Retrieved from https://www.oecd.org/corporate/committingto-effective-whistleblower-protection-9789264252639-en.htm

Organisation for Economic Co-operation and Development (2018). G20 Anti-Corruption Action Plan. Retrieved from https://www.ag.gov.au/Integrity/AntiCorruption/Documents/G20AntiCorruptionActionPlan.pdf

Panama Papers: Juncker si difende (2017, 30 May), Euronews. Retrieved from https://it.euronews.com/2017/05/30/panama-papers-juncker-si-difende

Pearson, L. (2019). Historic day for whistleblowers as EU agrees pathbreaking legislation [Press release]. Retrieved from:

https://www.transparency.org/news/pressrelease/historic_day_for_whistleblowers_as_eu_agree s_pathbreaking_legislation

Princen, S. (2010). Agenda-Setting. In E. Versluis, M. Van Keulen, and P. Stephenson (Eds.), Analyzing the European Union policy process. Basingstoke: Macmillan International Higher Education.

Reda, J. (2016, July 1). Luxleaks verdict against two whistle-blowers contradicts intention of legislators as trade secrets directive is misquoted [Blog post]. Retrieved from https://juliareda.eu/2016/07/luxleaks-verdict-misquote/.

Reda, J. (2018, April 23). EU protection for whistleblowers is coming [Blog post]. Retrieved from https://juliareda.eu/2018/04/eu-whistleblower-protection/

Rhodes, R.A.W. (2008). Policy network analysis. In M. Moran, M. Rein, and R. E. Goodin (Eds.), The Oxford handbook of public policy. Oxford/New York: Oxford University Press.

Richardson, J. (2006). Policy-making in the EU: interests, ideas and garbage cans of primeval soup. In J. Richardson (Ed.), European Union Power and Policy-making, Abingdon: Routledge.

Rothschild, J., and Miethe, T. D. (1999). Whistle-blower disclosures and management retaliation. Work and Occupations 26(1), 107-128.

Sabatier, P. (1988). An advocacy coalition framework of policy change and the role of policy orientated learning therein. Policy Sciences, 21(2-3), 128-168.

Savage, C. (2019, 23 May). Assange Indicted Under Espionage Act, Raising First Amendment Issues, New York Times. Retrieved from https://www.nytimes.com/2019/05/23/us/politics/assangeindictment.html 
Schulze, M. (2015). Patterns of surveillance legitimization: The German discourse on the NSA scandal. Surveillance \& Society, 13(2), 197-217.

Transparency International (2013). European Parliament elections 2014: Anti-Corruption Pledge/Declaration against Corruption. Retrieved from: http://anticorruptionpledge.eu/static/pledge.pdf

Transparency International (2018). Whistleblower Protection in the European Union. Analysis and Recommendation on the proposed EU Directive. Retrieved from: https://transparency.eu/wpcontent/uploads/2018/08/Transparency-International-Position-paper-EU-WhistleblowerDirective-003.pdf

Transparency International (n.d.). Our Organisation. Retrieved from: https://www.transparency.org/whoweare/organisation

UK Department of Transport (1987). The Merchant Shipping Act 1894 mv Herald of Free Enterprise (Report No. 8074). Retrieved from: https://assets.publishing.service.gov.uk/media/54c1704ce5274a15b6000025/FormalInvestigati on_HeraldofFreeEnterprise-MSA1894.pdf

United Nations Office on Drugs and Crime (2004). United Nations Convention against Corruption. Retrieved from https://www.unodc.org/documents/treaties/UNCAC/Publications/Convention/0850026_E.pdf

United Nations Office on Drugs and Crime (n.d.). Implementation Review Group. Retrieved from http://www.unodc.org/unodc/en/corruption/IRG/implementation-review-group.html

Valero, J. (2016, 11 January). Vestager: We should thank the Luxleaks whistleblowers, Euractiv. Retrieved from https://www.euractiv.com/section/digital/interview/vestager-we-should-thankthe-luxleaks-whistleblowers/

Vandekerckhove, W. (2010). European whistleblower protection: Tiers or tears?. In D. Lewis (Ed.), A Global Approach to Public Interest Disclosure, Cheltenham/Northampton MA: Edward Elgar.

Williams, B. (1985). Ethics and the limits of philosophy. London: Routledge.

Winterman, D. (2004, 6 October). Belmarsh - Britain's Guantanamo Bay?, BBC News. Retrieved from http://news.bbc.co.uk/2/hi/uk_news/magazine/3714864.stm.

Wolfe, S., Worth, M., Dreyfus, S., and Brown, A. J. (2014). Breaking the silence: strengths and weaknesses in G20 whistleblower protection laws. Retrieved from: https://blueprintforfreespeech.net/wp-content/uploads/2015/10/Breaking-the-SilenceStrengths-and-Weaknesses-in-G20-Whistleblower-Protection-Laws1.pdf

Worth, M. (2013). Whistleblowing in Europe. Legal Protection for whistleblowers in the EU. Transparency International. Retrieved from: https://www.transparency.org/whatwedo/publication/whistleblowing_in_europe_legal_protectio ns_for_whistleblowers_in_the_eu

Zahariadis, N. (2008). Ambiguity and choice in European public policy. Journal of European Public Policy, $15(4), 514-530$. 
Marble

24 Research

Papers 